\title{
SELECTION FOR SOME PRODUCTIVE TRAITS IN NORFA LAYING HENS
}

\author{
F.H. Abdou(1), M.E. Soltan ${ }^{(1)}$, A.A. Enab(1) and E. A. Abou Sada (2) \\ (1) Dept. of Poultry and Fish Production, Fac. of Agric., Menoufia Univ. \\ (2) Ministry of Commerce and Industry.
}

Received: Feb. 19, $2019 \quad$ Accepted: Mar. 6, 2019

\begin{abstract}
The present experiment has been carried out at the Poultry Experimental Farm, Faculty of Agriculture, Menoufia University, Shebin El-Kom, Egypt, during the period from 2013 to 2017 on Norfa chickens. Total number of 475 dams were used in the present experiment in the base population, first and second generations. Independent culling levels (ICL) method of selection has been applied on the selected flock $(\bar{X}+0.5 \mathrm{sd})$. The criterion of ICL method of selection was to select hens having at least average ENgod +0.5 sd on condition that egg size and body weight should be around the average flock.
\end{abstract}

Results obtained and conclusions can be summarized as follows:

The heritability estimates $\left(h^{2}\right)$ showed that Age $s M$ had low $h^{2}$ estimates, both of BW $W_{S M}$ and $B W_{M}$ showed moderate $h^{2}$ estimates, EW $W_{S M}$ showed moderate to high $h^{2}$ estimates while $E W_{M}$ had moderate $h^{2}$ estimates and the heritability estimates for $E N_{90 d}$ and $E N_{42} W_{k}$ were moderate to high. The expected genetic changes for Age ${ }_{S M}, B W_{S M}, B W_{M}, E W_{S M}, E W_{M}$, $E N_{90 d}$ and $E N_{42 W K}$ in the base population were $-1.12 \mathrm{~d}$. $41.82 \mathrm{~g} \cdot 22.28 \mathrm{~g}$ ، $1.19 \mathrm{~g} \cdot 0.46 \mathrm{~g}$ ، 3.57egg and 1.70 eggs respectively. While the actual genetic gains were7.79، 17.9، 0.093 ، -1.60 ، -1.60 ، $5.18 \mathrm{egg}$ and 8 eggs respectively. The expected genetic changes for Age $s M, B W_{S M}, B W_{M}, E W_{S M}, E W_{M}, E N_{90 d}$ and $\left.E N_{42 W K}\right)$ in the first generation of Norfa chicken were $1.69 \mathrm{~d}$ ، $22.43 \mathrm{~g}$ ،31.01 g ، $.89 \mathrm{~g}$ ،.32g ، $1.8 \mathrm{egg}$ and 1.27 eggs respectively. While the actual genetic gains were -13،-29.9،-38، -1 ، -1.180 5.8 egg and 5.24eggs, in the same order. The expected genetic changes for Age ${ }_{S M}, B W_{S M}, B W_{M}, E W_{S M}, E W_{M}, E N_{9 o d}$ and $E N_{42 W K}$ in the first generation of Norfa chicken were $1.31 \mathrm{~d}$., $26.14 \mathrm{~g}, .27 .73 \mathrm{~g}, 0.87 \mathrm{~g}$ $, 0.26 \mathrm{~g}, 2.95 \mathrm{egg}$ and 2.91 eggs respectively. While the actual genetic gains were -10، 30 ، -22 - -1.4 ، 1 ، 14.05 egg and 19.72 eggs respectively.

The actual genetic gains for $E N_{90 d}$ and $E N_{42} w_{k}$ were high than the expected genetic changes through the base population, first and second generations by applied the Independent culling levels. The selected line was better than the control line for productive traits in Norfa laying hens.

Key words: Selection, productive traits, Norfa.

\section{INTRODUCTION}

In Egypt, a lot of efforts have been done to improve indigenous chickens. The Egyptian indigenous breeds of chickens have many advantageous such as their high adaptability to local environment and genetic resistance to some serious diseases such as Marek's beside the highly acceptable taste and favorable flavor for its meat and egg products. Abdou et al. (2017) summarized the history of Norfa breed from 1980 to 2017. A base population of Norfa chickens was formed through crossing two indigenous breeds of chickens (Fayoumi and W-Baladi) with two strains of W. Leghorn imported from Norway in 1980 (L2 which was developed for high egg number and L7 which was developed for heavy egg weight). Generally, as layers Norfa chickens have low body weight (less than 1500g) which means 
low maintenance requirements and early sexual maturity Zanaty et al. (2001). Since 1980 till 2007 many researchers worked on Norfa strain. Enab (1982) evaluated the performance of parental purebreds (L2, L7 and Fayoumi). Abdou and Kolstad (1984) evaluated the performance of twoway crosses of the parental purebreds. Enab (1991) applied different selection indices (i.e. general, reduced, restricted and two - stage indices) in Norfa strain. Shebl et al. (1991) studied the genotypeenvironment interaction for growth and reproductive traits in Norfa chickens. Abou El-Ghar (1994) developed two divergent selected lines from Norfa strain on body weight by using tandem selection. Harfoush (1997) studied the effect of different management and environmental conditions (i.e. lighting, temperature and dietary protein level) on the performance of Norfa layers. ElSakka (1999) studied the effect of selection on some egg quality traits on Norfa strain. Abou El-Ghar and Abdou (2004) evaluated the hybrid vigor in egg production traits in the diallel crosses of different four lines of Norfa strain.

Abou Elewa (2004) studied the direct selection for general immune response and its relation to some economic traits in Norfa chickens. Ben-Naser (2007) developed two different specialized lines in body weight (i.e. light and heavy body weight lines) by using different selection indices (i.e. general, sub-indices, reduced and restricted indices) during two consequently generations of Norfa strain. El-Weshahy (2010) used independent culling levels method in three generations in three lines (EN, BW and control) for improving Norfa hens during three generations and crossing to get hybrid vigor for some egg production traits. Abou-Elewa et al. (2016) studied determination age at sexual maturity of cocks depending on the first response of semen collection and to characterize the semen parameters in Norfa chickens. Abdou et al. (2017) explained improving indigenous chickens in developing countries and showed the outlet of the Norwegian-Egyptian Project "NORFA" in Egypt (1980-2017).

The main aim of the present study is trying to improve some egg production traits of Norfa chickens by using independent culling levels method during the three generations.

\section{MATERIALS AND METHODS}

The present experiment has been carried out at the Poultry Experimental Farm, Faculty of Agriculture, Menoufia University, Shebin El-Kom,Egypt, during the period from 2013 to 2017 on Norfa chickens. Total of $\mathbf{4 7 5}$ dams were used in the present experiment in the base population, first and second generations.

The studied traits

1) Age at sexual maturity: (Age $\left.{ }_{S M}\right)$ : number of days at the first egg layed.

a) Egg number: $E_{90 d}$ : number of eggs in the first ninety days of laying.

b) EN 42weeks: Number of eggs at $\mathbf{4 2}$ weeks of age $\left(\mathrm{EN}_{42 \mathrm{WK}}\right)$.

2) Egg weight:

a) $E W_{S M}$ : average weight of the first 5 eggs at sexual maturity in grams.

b) $\mathrm{EW}_{\mathrm{M}}$ : average weight of 5 eggs during $(35-38)$ weeks of age $\left(E W_{M}\right)$ in grams

3) Body weights (BW):

a) Body weight at different ages. Body weight during the base population, first and second generation were taken at $0,4,8,12$ and 16 weeks of age (BW0, BW 4 ${ }_{4 k k}, B W_{8 w k}, B W_{12 w k}$ and $B W_{16 \mathrm{wk}}$ ).

b) $\mathrm{BW}_{\mathrm{SM}}$ : body weight at sexual maturity in grams.

c) BW ${ }_{42 w k}$ : body weight at 42 weeks of age in grams. 


\section{STATISTICAL ANALYSIS}

Studied traits were analyzed using general linier model (GLM), SAS computer program SAS (2002) as following two models:

Model I:

$Y_{i j}=\mu+G_{i}+e_{i j}$ Where:

$Y_{i j}=$ Observation on the $i^{\text {th }}$ chick.

$\mu=$ The overall mean of the trait.

$G_{i}=$ Effect of $j^{\text {th }}$ group (selected and control).

$\mathbf{e}_{\mathrm{ij}}=$ Random error.

The Least Squares Program SAS (2002) was also used to calculate the analysis of variance and least square means of all effects in the model. Standard deviation of the parameters was estimated and tests of the significances were applied. Furthermore, the least squares program SAS (2002) was used to estimate the analysis of variance overall two lines (selected and control lines) as well as to calculate least square means of all effects in the following mixed model which was used for overall lines:

Model II:

$Y_{i j k}=\mu+S_{i}+D_{i j}+e_{i j k}$ Where

$Y_{i j k}=$ The value of a trait of $k^{\text {th }}$ progery

from the $j^{\text {th }}$ dam mated to the $i^{\text {th }}$ sire.

$\mu=$ The overall mean of the trait.

$S_{i}=$ Random effect of the $i^{\text {th }}$ sire.

$D_{i j}=$ Random effect of the $j^{\text {th }}$ dam mated to $\mathrm{i}^{\text {th }}$ sire.

$\mathbf{e}_{\mathrm{ijkl}}=$ Random error component assumed to be normally distributed. The program calculates the values of Heritability, genetic and least square means for all effects in the model. Standard errors of these parameters and testing of significance were also given.

\section{GENETIC GAINS}

The expected genetic gains $(\Delta G)$ were calculated according to the formula given by (Prichener's, 1979) as follow.

$$
\Delta G=i . h j . \delta A j
$$

Where: $\mathrm{i}=$ Selection intensity.

hj $=$ Square root of heritability for the jth trait.

$\delta A j=$ Additive genetic standard deviation of the jth trait.

Actual genetic gain was calculated as deviation from the control line performance by equation given by Hill (1972) as follows:

Where:

$$
\Delta \mathbf{G}=\mathbf{( S t - C t )}
$$

$S$ and $C$ are the means of selected and control lines in generation number $(t)$.

\section{SELECTION PROCEDURES}

Independent culling levels method was applied in the three generations. All individuals that failed to come up with a certain standard for each trait and regardless of their record in any other trait, have been discarded.

During three generations of selection the independent culling levels procedure was applied in the base population to divide it into two lines (selected and control). The egg number line (EN) was determined by using the overall mean for egg number at 90 days of the base population plus 0.5 standard deviation $(\mu+0.5$ s.d), while body and egg weight should be around the average flock. The same selection method was applied in each of the following generation. Also, the cocks of the base population were divided into these three lines upon this procedure. The birds of the control line were chosen randomly before applying the independent culling levels. Norfa layers of the base flock had been faced some unfavorable conditions (ration shortage). Therefore selection under feed stress had applied on Norfa layers and this may be affected some low means of some performance.

\section{RESULTS AND DISCUSSION Heritability \\ The estimates of heritability of all}


F.H. Abdou, et al.,

studied traits (i.e. Age $_{S M}, \mathrm{BW}_{\mathrm{SM}}, \mathrm{BW}_{\mathrm{M}}$, $\mathrm{EW}_{\mathrm{SM}}, \mathrm{EW}_{\mathrm{M}}, \mathrm{EN}_{\text {90d }}$ and $\mathrm{EN}_{42 \mathrm{WK}}$ ) based on sire, dams and sire + dam variance components during the base population, first and second generation are presented in Table (1). Heritability estimates of age at sexual maturity $\left(\right.$ Age $\left._{\mathrm{SM}}\right)$ had the lowest heritability (h2) estimates while body weight at sexual maturity $\left(\mathrm{BW}_{\mathrm{SM}}\right)$ and body weight at maturity $\left(B W_{M}\right)$ had the highest estimates.

Generally, Table (1) shows that the estimate of heritability for age at sexual maturity was low. On the other hand, the heritability estimates of the body weight at sexual maturity or at maturity were moderate. Also, the heritability estimates of egg weight at sexual maturity, at maturity, egg mass of 90 day and egg mass of 42 weeks were lowest.
Furthermore, egg number during the first $90 \mathrm{~d}$ or till 42 week had moderate heritability estimates.

Most of the estimates were in a good agreement with those found on Norfa strain by Enab (1991), Sherif (1991), Enab et al. (1992), El-Wardany and Abdou (1993), Abou El-Ghar (1994), Enab (1996), Abou Sada (2007, Ben-Naser (2007), ElWeshahy (2010), Abou-Elewa (2010), Enab et al. (2015), Abou-Elewa et al. (2016) and Abdou et al. (2017) .

Moreover, some of heritability estimates were beyond of the biological limits (more than one or less than zero) and these illogical values may be found when the selection emphasized highly on some traits and $I$ or due to sampling errors Enab (1991).

Table (1): Heritability estimates of the studied traits in base population, first and second generations in Norfa chickens.

\begin{tabular}{||c|c|c|c|c|c|c||c|c|c||}
\hline \multirow{2}{*}{ Trait } & \multicolumn{3}{|c|}{ Base population } & \multicolumn{3}{c||}{ First generation } & \multicolumn{3}{c||}{ Second generation } \\
\cline { 2 - 10 } & $h^{2} \mathrm{~S} \pm \mathrm{SE}$ & $\begin{array}{c}h^{2} \mathrm{D} \pm \\
\mathrm{SE}\end{array}$ & $\begin{array}{c}\mathrm{h}^{2} \mathrm{~S}+\mathrm{D} \\
\pm \mathrm{SE}\end{array}$ & $h^{2} \mathrm{~S} \pm \mathrm{SE}$ & $\begin{array}{c}\mathrm{h}^{2} \mathrm{D} \pm \\
\mathrm{SE}\end{array}$ & $\begin{array}{c}h^{2} \mathrm{~S}+\mathrm{D} \\
\pm \mathrm{SE}\end{array}$ & $h^{2} \mathrm{~S} \pm \mathrm{SE}$ & $\begin{array}{c}h^{2} \mathrm{D} \pm \\
\mathrm{SE}\end{array}$ & $\begin{array}{c}h^{2} \mathrm{~S}+\mathrm{D} \\
\pm \mathrm{SE}\end{array}$ \\
\hline Age $_{\mathrm{SM}}$ & $.11 \pm .01$ & $.10 \pm 01$ & $.11 \pm .01$ & $.26 \pm .02$ & $.13 \pm .009$ & $.21 \pm .013$ & $.22 \pm .17$ & $.05 \pm .004$ & $.14 \pm .009$ \\
\hline \hline $\mathrm{BW}_{\mathrm{SM}}$ & $.86 \pm .07$ & $.26 \pm 02$ & $.72 \pm .04$ & $0.43 \pm .03$ & $41 \pm .02$ & $.49 \pm .03$ & $0.4 \pm 032$ & $.44 \pm .031$ & $.50 \pm .030$ \\
\hline \hline $\mathrm{BW}_{\mathrm{M}}$ & $.21 \pm .02$ & $.39 \pm 03$ & $.33 \pm .02$ & $.80 \pm .06$ & $.15 \pm .01$ & $.6 \pm .031$ & $.42 \pm .033$ & $.37 \pm .026$ & $.46 \pm .028$ \\
\hline \hline $\mathrm{EW}_{\mathrm{SM}}$ & $.17 \pm .01$ & $.72 \pm 05$ & $.54 \pm .03$ & $.33 \pm .027$ & $.56 \pm .039$ & $.52 \pm .031$ & $.44 \pm .036$ & $.38 \pm .027$ & $.43 \pm .026$ \\
\hline \hline $\mathrm{EW}_{\mathrm{M}}$ & $.12 \pm .01$ & $.28 \pm .02$ & $.22 \pm .01$ & $.02 \pm .002$ & $.33 \pm .023$ & $.19 \pm .011$ & $.12 \pm .010$ & $.13 \pm .009$ & $.13 \pm .008$ \\
\hline \hline $\mathrm{EN}_{90 \mathrm{~d}}$ & $.53 \pm .04$ & $.53 \pm .04$ & $.64 \pm .04$ & $.4 \pm .03$ & $.33 \pm .023$ & $.41 \pm .025$ & $.41 \pm .032$ & $.56 \pm .039$ & $.56 \pm 035$ \\
\hline \hline $\mathrm{EN}_{42 \mathrm{wk}}$ & $.33 \pm .03$ & $.09 \pm .01$ & $.23 \pm .01$ & $.37 \pm .03$ & $.02 \pm .002$ & $.21 \pm .013$ & $.41 \pm .033$ & $.33 \pm .02$ & $.43 \pm 026$ \\
\hline \hline $\mathrm{EM}_{90 \mathrm{~d}}$ & $0.30 \pm .02$ & $.25 \pm .02$ & $0.31 \pm .02$ & $.37 \pm .02$ & $.29 \pm .02$ & $.37 \pm .02$ & $.16 \pm .013$ & $.38 \pm .027$ & $.31 \pm .018$ \\
\hline \hline $\mathrm{EM}_{42 \mathrm{wk}}$ & $0.31 \pm .03$ & $.23 \pm .02$ & $0.30 \pm .02$ & $.53 \pm .042$ & $.03 \pm .002$ & $.32 \pm .019$ & $.34 \pm 028$ & $.31 \pm .002$ & $.37 \pm .022$ \\
\hline
\end{tabular}




\section{Selection Method of Independent culling levels.}

Selection method of independent culling (ICL) was applied to maximize the genetic gain of flock $\left(\bar{x}_{ \pm} 0.5 \mathrm{sd}\right)$. The main of selection of laying flock of the hen is to increase egg number. Increasing egg number should be done on condition that egg size is not affected due to the fact that increasing egg number is associated with decreasing body and egg weights. Therefore, selection program applied on laying flock always focused on increasing egg number on condition that egg and body weights should be around the main flock. Independent culling levels (ICL) method of selection has been applied on the selected flock $(\bar{x}+0.5 \mathrm{sd})$. The criterion of (ICL) method of selection was to select hens having at least average of $\mathrm{EN}_{90 \mathrm{~d}}+$ 0.5 on condition that egg size and body weight should be around the average flock. The averages were 41.1eggs for $E N_{90} \mathrm{~d} .38 \mathrm{~g}$ for $E W_{S M}$ and $1013.5 \mathrm{~g}$ for $B W_{S M}$. The differences among these means were significant $(.05)$.

The expected and actual genetic changes by applying independent culling levels for the base population

Table (2) illustrated expected and actual genetic gains for all traits of selected flock. Table (33) shows that the expected genetic changes of Age ${ }_{s M}$, $B W_{S M}, B W_{M}, E W_{S M}, E W_{M}, E N_{90 d}$ and $\mathrm{EN}_{42 \mathrm{Wk}}$ for the base population were -1.12 d., $41.82 \mathrm{~g}, 22.28 \mathrm{~g}, 1.19 \mathrm{~g}, .46 \mathrm{~g}, 3.57 \mathrm{egg}$ and 1.70 eggs respectively. While the actual genetic gains were -7.79, 17.9, $0.093,-1.60,-1.60,5.18$ egg and 8 eggs. The results in Table (2) show that there was a good agreement between the actual and expected genetic change for $B W M$ and $E N_{90 d}$. On the other hand there was a clear discrepancy between the actual and expected genetic change for $A_{S M}, B W_{S M}, E W_{S M}, E W_{M}$ and $E_{42 w k}$.

Most of the estimates were in a good agreement with those found on Norfa strain by Abdou et al. (1998), El-Sakka (1999), Abou El-Ghar (2003), Ben Nasr (2007), Abou-Elewa (2010) and, ElWeshahy, (2010).

These discrepancies between the actual and expected genetic changes might be due to missing progeny of some selected dams and sampling errors.

Table (2): Means \pm sd of the base population, expected genetic gain and Actual genetic gain in the base population.

\begin{tabular}{|c|c|c|c|c|}
\hline Trait & $\begin{array}{c}\text { base population } \\
\text { Means } \pm \text { sd } \\
\text { of the selected line }\end{array}$ & $\begin{array}{c}\text { Means } \pm \text { sd of } \\
\text { the control line }\end{array}$ & $\begin{array}{c}\text { Expected } \\
\text { genetic gains }\end{array}$ & $\begin{array}{c}\text { Actual } \\
\text { genetic gains }\end{array}$ \\
\hline Age $_{\mathrm{SM}}$ & $162.2 \pm 10.14$ & $170 \pm 17.725$ & 1.12 & -7.79 \\
\hline $\mathrm{BW}_{\mathrm{SM}}$ & $1013.5 \pm 96.34$ & $1028.483 \pm 62.54$ & 41.82 & -14.5 \\
\hline $\mathrm{BW}_{\mathrm{M}}$ & $1221.953 \pm 110.74$ & $1204 \pm 83.621$ & 22.28 & 17.9 \\
\hline $\mathrm{EW}_{\mathrm{SM}}$ & $37.90 \pm 4.058$ & $38.0 \pm 4.1$ & 1.19 & -0.093 \\
\hline $\mathrm{EW}_{\mathrm{M}}$ & $41.395 \pm 3.54$ & $43.0 \pm 3.4$ & 0.46 & -1.60 \\
\hline $\mathrm{EN}_{90 \mathrm{~d}}$ & $41.18 \pm 4.31$ & $36.0 \pm 5.15$ & 3.57 & 5.18 \\
\hline $\mathrm{EN}_{42 \mathrm{wk}}$ & $64.0 \pm 2.24$ & $56.0 \pm 5.963$ & 1.70 & 8 \\
\hline
\end{tabular}


F.H. Abdou, et al.,

4.5. The expected and actual genetic changes by applying independent culling levels for the first generation

Table (3) shows that the expected genetic changes of $\mathrm{Age}_{\mathrm{SM}}, \mathrm{BW}_{\mathrm{SM}}, \mathrm{BW}_{\mathrm{M}}$, $E W_{S M}, E W_{M}, E N_{90 d}$ and $E_{42 W K}$ for the first generation of Norfa chicken were $1.69 \mathrm{~d}$., $22.43 \mathrm{~g}, 31.01 \mathrm{~g}, .89 \mathrm{~g}, .32 \mathrm{~g}, 1.8$ egg and 1.27 eggs respectively. While the actual genetic gains were $-13,-29.9,-38$, $-1,-1.180,5.8$ egg and 5.24 eggs respectively. This low expected genetic gains for egg number were mainly due to mainly to low heritability estimates (i.e. .41 and .21 for EN ${ }_{90 d}$ and $\left.E_{42 w K}\right)$. On the other hand there was a clear discrepancy between the actual and expected genetic change for all traits.

Most of the estimates were in a good agreement with those found on Norfa strain by Abdou et al. (1998), El -Sakka (1999), Abou El-Ghar (2003), Ben Nasr
(2007), Abou-Elewa (2010) and ElWeshahy, (2010).

4.6. The expected and actual genetic changes by applying independent culling levels for the second generation.

Table (4) illustrates, expected genetic changes of $A_{S M}, B W_{S M}, B W_{M}, E W_{S M}$, $E W_{M}, E N_{90 d}$ and $E N_{42 W k}$ for the second generation of Norfa chicken being $1.31 \mathrm{~d}$., $26.14 \mathrm{~g}, 27.73 \mathrm{~g}, .87 \mathrm{~g}, .26 \mathrm{~g}, 2.95 \mathrm{egg}$ and 2.91 eggs respectively. While the actual genetic gains were -10, -30, -22$1.4,1,14.05$ egg and 19.72 eggs in the same order. On the other hand there was a clear discrepancy between the actual and expected genetic change for all traits.

Most of the estimates were in a good agreement with those found on Norfa strain by Abdou et al. (1998), El-Sakka (1999), Kosba et al. (2002), Abou El-Ghar (2003), Ben Nasr (2007), Abou-Elewa (2010), El-Weshahy, (2010).

Table (3): Means \pm sd of the first generation, Expected genetic gain and Actual genetic gain in the first generation.

\begin{tabular}{|c|c|c|c|c|}
\hline Trait & $\begin{array}{c}\text { first generation } \\
\text { Means } \pm \text { sd } \\
\text { of the selected line }\end{array}$ & $\begin{array}{c}\text { Means } \pm \text { sd of the } \\
\text { control line }\end{array}$ & $\begin{array}{c}\text { Expected } \\
\text { genetic } \\
\text { gains }\end{array}$ & $\begin{array}{c}\text { Actual } \\
\text { genetic } \\
\text { gains }\end{array}$ \\
\hline Age & $158 \pm 18.15$ & $171 \pm 13.61$ & 1.69 & -13 \\
\hline $\mathrm{BW}_{\mathrm{SM}}$ & $1008.172 \pm 87.002$ & $1038.6 \pm 55.9$ & 22.43 & -29.9 \\
\hline $\mathrm{BW}_{\mathrm{M}}$ & $1188 \pm 111.151$ & $1226 \pm 86.462$ & 31.01 & -38 \\
\hline $\mathrm{EW}_{\mathrm{SM}}$ & $38.0 \pm 03.863$ & $39.0 \pm 3.46$ & 0.89 & -1 \\
\hline $\mathrm{EW}_{\mathrm{M}}$ & $41.17 \pm 3.299$ & $42.3 \pm 3.2$ & 0.32 & -1.18 \\
\hline $\mathrm{EN}_{90 \mathrm{~d}}$ & $48.155 \pm 5.896$ & $42.28 \pm 2.59$ & 1.80 & 5.87 \\
\hline $\mathrm{EN}_{42 \mathrm{wk}}$ & $72.466 \pm 8.185$ & $67.16 \pm 5.46$ & 1.27 & 5.24 \\
\hline
\end{tabular}


Table (4): Means \pm sd of the second generation, Expected genetic gain and Actual genetic gain the second generation.

\begin{tabular}{|c|c|c|c|c|}
\hline Trait & $\begin{array}{c}\text { second generation } \\
\text { Means } \pm \text { sd } \\
\text { of the selected line }\end{array}$ & $\begin{array}{c}\text { Means } \pm \text { sd of the } \\
\text { control line }\end{array}$ & $\begin{array}{c}\text { Expected } \\
\text { genetic } \\
\text { gains }\end{array}$ & $\begin{array}{c}\text { Actual } \\
\text { genetic } \\
\text { gains }\end{array}$ \\
\hline Age $_{\mathrm{SM}}$ & $152 \pm 11.7$ & $162 \pm 7.5$ & 1.31 & -10 \\
\hline $\mathrm{BW}_{\mathrm{SM}}$ & $980 \pm 88.4$ & $1010.618 \pm 109.9$ & 26.14 & -30 \\
\hline $\mathrm{BW}_{\mathrm{M}}$ & $1210.82 \pm 88.2$ & $1233.088 \pm 111.9$ & 27.73 & -22 \\
\hline $\mathrm{EW}_{\mathrm{SM}}$ & $35.084 \pm 2.0$ & $36.437 \pm 2.0$ & 0.87 & -1.4 \\
\hline $\mathrm{EW}_{\mathrm{M}}$ & $42.0 \pm 3.2$ & $41.0 \pm 3.4$ & 0.26 & 1 \\
\hline $\mathrm{EN}_{90 \mathrm{~d}}$ & $63.525 \pm 13.1$ & $49.471 \pm 4.2$ & 2.95 & 14.05 \\
\hline $\mathrm{EN}_{42 \mathrm{wk}}$ & $92.279 \pm 18.4$ & $72.559 \pm 6.4$ & 2.91 & 19.72 \\
\hline
\end{tabular}

\section{REFERENCES}

Abdou, F. and N. Kolstad (1984). A study on the performance of Norwegian and Egyptian breeds of laying hens and their crosses. Proc. XVII. World poult. Confr. Exhib., Helsinki, p. (123 - 125)

Abdou, F., A. Enab and N. Kolstad (1998). Use of supplementary information of residual feed consumption in selection programs for laying hens. Proc. $87^{\text {th }}$ Ann. meeting of PSA, the Pennsylvania State Univ. 77:266 (Abstr.)..

Abdou, F.H., A. A. Enab, A.A. El-Fiky and Kolstad (2017). Improving indigenous chickens in developing countries outlet of the Norwegian-Egyptian project "NORFA" in Egypt (1980-2016). Proceeding of the Poultry Science Association Annual meeting, 17-20 July, 2017, Orlando, Florida, USA.

Abou- Elewa, E. (2010). Some genetic parameters of the immune response trait and its utilization in different selection methods in chickens.

Abou El-Ghar, R. (2003). Combining ability and genetic gain of some economic traits in Norfa chickens. Ph.
D. Thesis, Facu. Agric. Minufiya Univ., Egypt.

Abou El-Ghar, R. and F. H. Abdou (2004). Evaluation of genetic variance components based on the concept of generation means for some economic traits in chickens. Egypt. Poult. Sci. Vol. 24 (III): 687-699.

Abou El-Ghar, R. (1994). Genetic studies of some productive traits in chickens. M. Sc. Thesis, Facu. Agric., Minufiya Univ., Egypt.

Abou Sada, E. (2007). Selection for some economic traits in Norfa layers utilizing selection indices. M. Sc. Thesis, Fac. of Agric. Minoufia Univ., Egypt. .

Abou-Elewa, E.M., A.A. Enab and F.H. Abdou (2016). Sexual maturity of male chickens according to early response of semen milking. Proceeding of the 9th International Poultry Conference, 7 - 10 November 2016, Hurghada, Red Sea - Egypt.

Abou-Elewa, E. (2004). Selection for general immune response and its relation to some economic traits in chickens. M. Sc. Thesis, Facu. Agric., Minufiya Univ., Egypt. 
Ben Naser, K. (2007). Using selection to improve some economic traits in Norfa chickens. Ph. D. Thesis, Fac. Agric. Minufiya Univ., Egypt.

El-Sakka, M. (1999). Expected and realized genetic gain of some egg quality traits in chickens. M. Sc. Thesis, Facu. Agric., Minufiya Univ., Egypt.

El-Wardany, A. and F.H. Abdou (1993). Genetic analysis of two strains of Norfa chickens under selection for egg number or size. Minufiya J. Agric. Res. 18 : 241 - 256.

El-Weshahy, O. (2010). Genetic improvement of some economic traits in Norfa chickens. In progress. Ph.D. Thesis, Fac. Agric. Minufiya Univ., Egypt.

Enab, A. (1982). Genetic analysis of some economic traits in chickens. M. Sc. Thesis, Facu. Agric., Minufiya Univ., Egypt.

Enab, A. (1991). The using of different selection indicies to improve some economic traits in laying hens. Ph. D. Thesis, Minufiya Univ., Egypt.

Enab, A. (1996). Genetic progress achieved in some egg production traits by using supplementary family information in selection indices. Egypt. Poult. Sc. 16 (II): 251-267.

Enab, A., M. Soltan, F. Abdou and G. Gebriel (1992). Expected vs. Actual response to selection in Norfa chickens. Minufiya Jou. Agric. Res. 17: 1865 - 1886.
Enab, A.A. M.E. Soltan, F.H. Abdou and Hend E. Elnoamany (2015). Studies on some productive traits in Norfa chickens. minufiya j.agric, res., vol. 40 no. 4 (1): 915-923.

Harfoush, M. (1997). A study on the effects of some genetic and environmental factors on egg production of chickens. M. Sc. Thesis, Facu. Agric, Minufiya Univ., Egypt.

Hill, W.G. (1972). Estimation of genetic change. 2. Experimental evaluation of control population. Anim. Br. Abstr. 40 : 193 - 213.

Kosba, M., M. Farghaly, M. Bahie El-Deen and H. Abd El-Halim (2002). Selection and genetic analysis of some egg production traits in local chickens. Egypt. Poult. Sci. 22: 681 - 696.

Pirchener, F. (1979). Population genetik in der tierzucht. Poult. Parey, Hamburg and Berlin.

SAS Institute (2002). User, S Guide Statistics. SAS Institute INC., Cary, NC, USA.

Shebl, M., M. Soltan, M. Kosba and F. Abdou (1991). Genotype-Environment interactions for growth and reproductive traits in Norfa chickens. Minufiya. Jou. Agric. Res. 16: 1439 1455.

Zanaty, G., A. Rady, A. Abou-Ashour and F. H. Abdou (2001). Productive performance of Norfa chickens as affected by dietary protein levels, brooding system and season. Egypt. Poult. Sci. 21 (1): 237-254. 


\section{الإنتخاب لبعض الصفات الإنتاجية فى دجاج النورفا البياض}

\section{فاروق حسن عبده(1) ، محمد السيد سلطان(') ،أحمد عبد الوهاب عنب(1)}

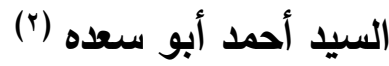

(1) قسم إنتاج الاواجن والأسماك ، كليـة الزراعـة ، جامعة/لمنوفية (ז) التزاره التجاره الخارجيه والصناعه الملخص العربى

أجريت هذه الداسة في مزرعة الدواجن - كلية الزراعة - جامعة المنوفية بشبين الكوم جمهورية مصر العربية كجزء

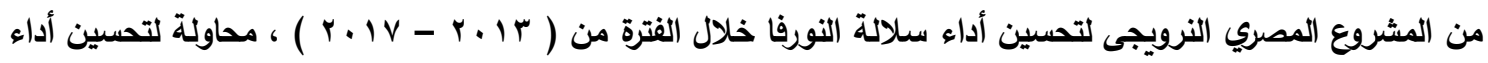

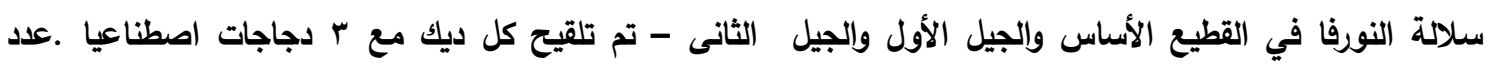

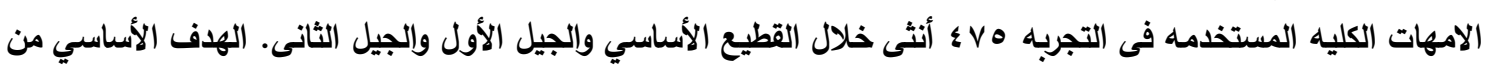

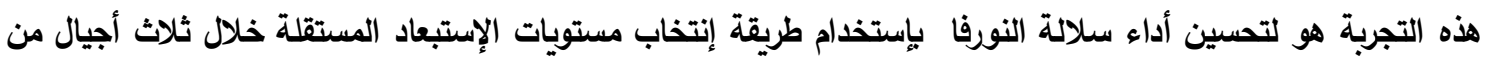

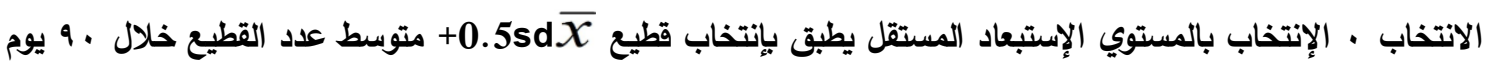
2sd ويمكن تلخيص النتائج المتحصل عليها كالآتي: بصفة عامة كانت قيمة المكافئ الوراثي للعمر عند النضج الجنسي منخفضة في حين كانت قيمة المكافئ الوراثي لكل

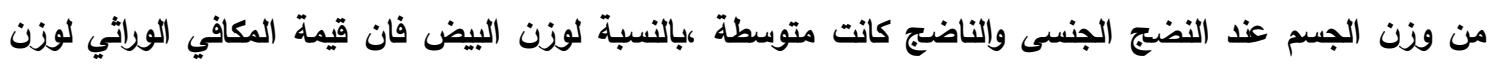

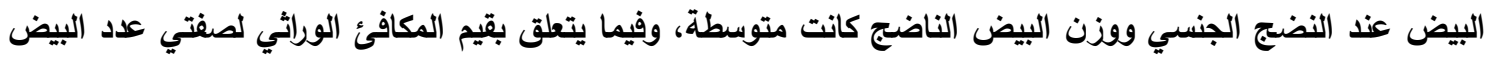
حتي • 9 يوم الاولي وحتي ب ؛ اسبوع فقد كانت مابين المتوسطة الى المرتفعة.

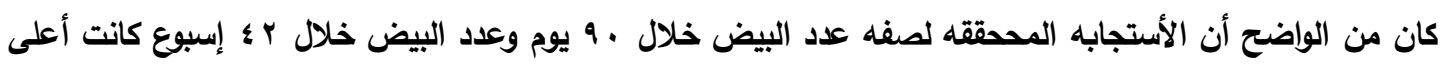
من الإستجابه المتوقعه خلال قطيع الأساس والجيل الأول والثانى بواسطه تطبيق الإنتخاب بالمستويات الاستبعادية المستقلة. أوضحت النتائج في هذه الدارة تفوق الخط المنتخب عن خط الكترول في الصفات الإنتاجيه فى دجاج النورفا

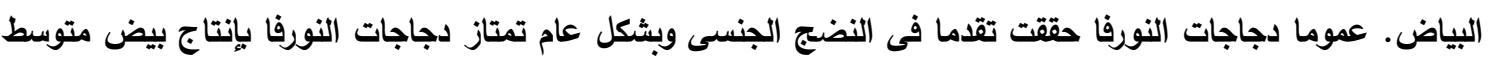
الحجم وهذا يرجع الى أن متوسط وزن الجسم لهذه السلالة . لؤل 
F.H. Abdou, et al., 